\title{
PEMERIKSAAN DAN PENYULUHAN GLUKOSA DARAH DAN ASAM \\ URAT PADA LANSIA DI RW 22 KELURAHAN NUSUKAN \\ KECAMATAN BANJARSARI KOTA SURAKARTA
}

\author{
Rahmat Budi Nugroho
}

rahmat.bn17@gmail.com

\begin{abstract}
ABSTRAK
Kelurahan Nusukan merupakan salah satu kelurahan yang terdapat pada Kecamatan Banjarsari, Kota Surakarta. Kawasan ini mempunyai jumlah penduduk usia lanjut yang cukup banyak. Dari hasil observasi yang telah dilakukan, kelurahan Nusukan terutama di RW 22 sudah terdapat Posyandu Lansia, namun dalam pelaksanaannya jarang sekali dilakukan pemeriksaan kesehatan, khususnya pemeriksaan kadar glukosa darah dan asam urat. Oleh sebab itu diperlukan pemeriksaan kadar glukosa darah dan asam urat agar warga lansia di RW 22 Kelurahan Nusukan dapat memantau kondisi kesehatannya dengan lebih mudah.

Tujuan dari program kegiatan pengabdian masyarakat ini adalah memberikan gambaran bagi lansia tentang kadar glukosa darah dan asam urat total serta memberikan penyuluhan tentang pengaturan pola hidup sehat bagi lansia.

Hasil pemeriksaan diketahui bahwa dari 35 lansia yang diperiksa, yang memiliki kadar glukosa darah normal sebanyak 15 orang, beresiko diabetes mellitus sebanyak 10 orang, sedangkan 10 orang lainnya memiliki penderita diabetes.
\end{abstract}

Kata kunci : lansia, asam urat, glukosa darah, degeneratif

\section{PENDAHULUAN}

Proses penuaan merupakan siklus kehidupan yang ditandai dengan tahapan menurunnya berbagai fungsi organ tubuh, yang ditandai dengan semakin rentannya tubuh terhadap berbagai serangan penyakit yang dapat menyebabkan kematian misalnya pada sistem kardiovaskuler dan jantung koroner (32\%), hipertensi $(31,7 \%)$, arthritis $(30,3 \%)$, cedera (7,5\%) dan lain-lain. Kemunduran fungsi organ yang dialami oleh lansia menyebabkan kelompok ini rawan terkena penyakit degeneratif (Kemenkes, 2013).

Seiring dengan bertambahnya usia terjadi penurunan aktivitas fisik dan fungsi organ pada seseorang khususnya lansia, sehingga para lansia sangat rawan terkena penyakit degeneratif. Angka kejadian penyakit degeneratif semakin 
meningkat yang disebabkan oleh meningkatnya angka harapan hidup, gaya hidup tidak sehat, dan tingkat kesembuhan terhadap penyakit-penyakit infeksi semakin tinggi. Sebelum penemuan antibiotik angka kejadian dan angka kematian karena penyakit-penyakit infeksi masih tinggi. Di Indonesia, penyakit-penyakit degeneratif mulai menjadi perhatian karena meningkatnya angka kejadian dan angka kematian.

Penyakit degeneratif yang sering dijumpai adalah asam urat. Asam urat merupakan hasil metabolisme di dalam tubuh yang terbentuk dari pemecahan zat purin yang ada di dalam sel-sel tubuh. Asam ini dibuang dari tubuh melalui ginjal. Jika asam urat yang dibuang dari tubuh jauh lebih sedikit dari jumlah produksinya, maka sisanya akan menumpuk di dalam dan sekitar sendi dalam bentuk kristal-kristal tajam natrium urat. Pembentukan dan penumpukan kristalkristal tersebut bisa berlangsung selama bertahun-tahun tanpa disadari.

Kadar asam urat di dalam darah yang meningkat dapat menyebabkan penyakit asam urat. Asam urat sebagai hasil samping pemecahan sel terdapat secara normal dalam darah karena tubuh secara berkesinambungan memecah dan membentuk sel yang baru. Kadar asam urat meningkat atau abnormal ketika ginjal tidak sanggup mengeluarkan asam urat melalui air kemih. Tubuh menyediakan 85 $\%$ senyawa purin untuk kebutuhan setiap harinya, sedangkan purin yang didapat dari makanan hanya sekitar $15 \%$ (Prapti, 2005).

Kelurahan Nusukan adalah salah satu kelurahan yang terdapat pada kecamatan Banjarsari, Kota Surakarta. Kawasan ini mempunyai jumlah penduduk usia lanjut yang cukup banyak. Dari hasil observasi yang telah dilakukan, kelurahan Nusukan terutama di RW 22 sudah terdapat Posyandu Lansia, namun dalam pelaksanaannya jarang dilakukan pemeriksaan kesehatan, khususnya pemeriksaan kadar glukosa darah dan asam urat. Untuk itu perlu dilakukan penyuluhan dan pemeriksaan kesehatan kepada warga masyarakat agar dapat memberikan pemahaman kepada masyarakat tentang asam urat, penyebab, gejala, pengobatan dan pencegahan. Hal ini dimaksudkan agar kesehatan dan harapan hidup masyarakat semakin meningkat. 
Kegiatan dari Tri Darma Perguruan Tinggi salah satunya adalah pengabdian masyarakat. Dosen melakukan pengabdian kepada masyarakat untuk membantu permasalahan yang ada di masyarakat terutama bagi masyarakat yang ada di lingkungan sekitar Universitas Setia Budi. RW 22 Kelurahan Nusukan, merupakan daerah yang tidak jauh dari Universitas Setia Budi. Populasi lansia di RW yang menderita penyakit diabetes melitus cukup banyak. Padahal pemeriksaan kesehatan jarang dilakukan. Tujuan diadakannya pemeriksaan glukosa darah dan asam urat pada penderita diabetes melitus ini adalah untuk memberikan pendidikan kesehatan sehingga para lansia bisa menerapkan pola hidup sehat dan mengusahakan kadar glukosa darah dan asam urat selalu terkontrol untuk mencegah komplikasi penyakit diabetes melitus.

Tujuan dari kegiatan pengabdian ini adalah:

a. Melaksanakan Tri Dharma Perguruan Tinggi.

b. Meningkatkan pengetahuan masyarakat tentang pentingnya pola hidup sehat dan bahaya komplikasi diabetes mellitus.

c. Memberikan gambaran bagi lansia tentang kadar glukosa darah dan asam urat

d. Penyuluhan tentang penyakit diabetes mellitus dan hubunganya dengan kadar glukosa darah dan asam urat

e. Membantu pihak pemerintah dalam rangka mengurangi angka kematian yang disebabkan oleh penyakit degeneratif

Manfaat dari kegiatan ini adalah :

a. Bentuk kepedulian kepada masyarakat yang diaplikasikan dalam kegiatan pengabdian masyarakat.

b. Masyarakat mengetahui kadar glukosa darah dan asam urat dan kaitannya dengan penyakit diabetes mellitus.

c. Menambah wawasan masyarakat tentang pentingnya pola hidup sehat

\section{Diabetes Mellitus}

Diabetes mellitus (DM) adalah suatu penyakit atau gangguan metabolisme kronis dengan multi etiologi yang ditandai dengan tingginya kadar gula darah disertai dengan gangguan metabolisme karbohidrat, lipid dan proteinsebagai 
akibat insufisiensi fungsi insulin (Ditjen Bina Farmasi dan Alkes, 2005). Diabetes Mellitus juga dapat diartikan sebagai sekumpulan gejala yang timbul pada seseorang yang disebabkan oleh karena adanya peningkatan kadar gula (glukosa) darah akibat kekurangan insulin baik absolut maupun relatif. Insulin adalah hormon yang diproduksi sel beta di pankreas, sebuah kelenjar yang terletak di balakang lambung yang berfungsi mengatur metabolisme glukosa menjadi energi serta mengubah kelebihan glukosa menjadi glikogen yang disimpan di dalam hati dan otot. Seseorang dapat dikatakan memiliki resiko terserang penyakit diabetes apabila diketahui pada pemeriksaan kadar gula darah dalam puasanya melebihi angka $126 \mathrm{mg} / \mathrm{dl}$ atau dua kali berturut-turut pemeriksaan gula darah 2 jam sesudah makan, angka yang didapat melebihi 180 $\mathrm{mg} / \mathrm{dL}$ (Sustrani, 2006).

Adapun ciri-ciri orang terkena diabetes militus adalah rasa haus yang berlebihan, sering kencing terutama malam hari dan berat badan turun dengan cepat. Selain itu juga mudah lelah dan sering mengantuk, sering merasakan pusing dan mual, jika penderita mengalami luka, penyembuhan lukanya buruk, sering merasakan kesemutan pada tangan dan kaki, koordinasi gerak anggota tubuh terganggu.

\section{Asam Urat}

\section{a. Pengertian Asam Urat}

Asam urat adalah bahan normal dalam tubuh dan merupakan hasil akhir dari metabolisme purin, yaitu hasil degradasi purine nucleotide yang merupakan bahan penting dalam tubuh sebagai komponen dari asam nukleat dan penghasil energi dalam inti sel (Trisnadewi, 2014). Asam urat merupakan produk yang tidak dapat dimetabolisme lebih lanjut. Hanya 5\% asam urat yang terikat plasma dan sisanya akan difiltrasi secara bebas oleh glomerulus. Dari semua asam urat yang difiltrasi, 99\% akan direabsorpsi oleh tubulus proksimal. Kemudian 7-10\% raksi asam urat akan disekresi oleh tubulus distal (Vedercchia dalam Mustafiza, 2010).

Kadar normal asam urat dalam darah adalah 2-6 mg/dL untuk perempuan dan 3-7,2 mg/dL untuk laki-laki. Meningkatnya kadar asam urat dalam darah 
disebut hiperurisemia. Peningkataan kadar asam urat dapat mengakibatkan gangguan pada tubuh manusia seperti perasaan linu-linu di daerah persendian dan sering disertai timbulnya rasa nyeri yang teramat sangat bagi penderitanya (Andry dkk, 2009).

\section{b. Gejala Klinis}

Keluhan utama saat serangan akut adalah nyeri sendi yang teramat sangat disertai bengkak, hangat, memerah, dan nyeri tekan, biasanya disertai demam. Persendiaan yang pertama kali terkena yaitu ibu jari kaki dan bagian lain dari ekstremitas bawah, sedangkan pada gout menahun akan terjadi pembentukan tofus. Tofus merupakan benjolan dari kristal monosodium urat yang menumpuk di jaringan lunak tubuh (Komariah, 2015).

\section{c. Faktor-faktor yang mempengaruhi asam urat}

Faktor risiko penyebab orang terserang penyakit asam urat yaitu :

1) Genetik /riwayat keluarga

Asam urat dapat menjadi penyakit keturunan, dimana penderita mesti berhati-hati terutama dalam pola makan dan gaya hidup.

2) Stress

Penderita yang menerima stress dapat menyebabkan kadar asam urat dalam serum meningkat.

3) Asupan senyawa purin berlebihan

Bahan pangan yang tinggi kandungan purinnya dapat meningkatkan kadar urat dalam darah antara $0,5-0,75 \mathrm{~g} / \mathrm{ml}$ purin yang dikonsumsi. Konsumsi lemak atau minyak tinggi seperti makanan yang digoreng, santan, margarin atau mentega dan buahbuahan yang mengandung lemak tinggi seperti durian dan alpukat juga berpengaruh terhadap pengeluaran asam urat.

4) Konsumsi alkohol berlebih

Minum alkohol dapat menimbulkan serangan gout karena alkohol meningkatkan produksi asam urat. Kadar laktat darah meningkat akibat produk sampingan dari metabolisme normal alkohol. Asam 
laktat menghambat ekskresi asam urat oleh ginjal sehingga terjadi peningkatan kadarnya dalam serum.

5) Kegemukan (obesitas)

Seseorang dinyatakan obesitas jika indeks massa tubuh (IMT) lebih dari 30. Obesitas merupakan salah satu faktor gaya hidup yang berkontribusi terhadap kenaikan asam urat selain diet tinggi purin dan konsumsi alkohol.

6) Hipertensi dan penyakit jantung

Asam urat merupakan faktor risiko untuk penyakit jantung koroner. Diduga kristal asam urat akan merusak endotel (lapisan bagian dalam pembuluh darah koroner).

7) Obat-obatan tertentu (terutama diuretika)

Obat anti hipertensi, terutama thiazide diduga secara tidak langsung mempengaruhi metabolisme lemak yang pada akhirnya mengurangi pengeluaran asam lemak.

8) Gangguan fungsi ginjal

Sebagian besar atau hampir dua pertiga bagian asam urat dibuang oleh ginjal melalui urin, karena itu gangguan fungsi ginjal merupakan penyebab utama hambatan pembuangan asam urat.

9) Aktivitas fisik

Salah satu penyebab yang mempengaruhi kadar asam urat adalah olah raga atau aktivitas fisik. Olah raga atau gerakan fisik akan menyebabkan peningkatan kadar asam laktat. Asam laktat terbentuk dari proses glikolisis yang terjadi di otot. Jika otot berkontraksi didalam media anaerob, yaitu media yang tidak memiliki oksigen maka glikogen yang menjadi produk akhir glikolisis akan menghilang dan muncul laktat sebagai produksi akhir utama.

10) Umur

Proses penuaan akan mengakibatkan gangguan dalam pembentukan enzim urikinase yang mengoksidasi asam urat menjadi alotonin yang mudah dibuang. Jika pembentukan enzim ini terganggu 
maka kadar asam urat darah menjadi naik. Penyakit asam urat lebih sering menyerang pria di atas 30 tahun. Hal ini disebabkan pria mempunyai kandungan asam urat dalam darah lebih tinggi dibanding wanita yang baru meningkat setelah menopause.

11) Berat badan berlebih

Kondisi berat badan yang berlebih dapat menyebabkan asam urat. Hal ini disebabkan lemak yang banyak terdapat pada tubuh orang gemuk menghambat pengeluaran asam urat melalui urin.

12) Gangguan fungsi ginjal

Asam urat dikeluarkan bersama urin melalui ginjal. Jika terjadi gangguan pada ginjal, pengeluaran asam urat juga terganggu.

13) Penyakit degeneratif (hipertensi, jantung, diabetes mellitus)

Asam urat merupakan penyakit pokok dan menjadi penyerta dari penyakit degeneratif. Jika kadar asam urat tinggi, perlu dicurigai adanya penyakit degeneratif.

\section{PELAKSANAAN}

A. Identifikasi dan Observasi Permasalahan

Kegiatan pengabdian ini direncanakan dilaksanakan sebanyak 3 kali pertemuan dan mengundang 35 lansia. Masyarakat yang tinggal di RW 22 memiliki latar belakang yang berbeda-beda dari segi pendidikan, ekonomi, sosial dan budaya. RW 22 merupakan wilayah yang mempunyai jumlah penduduk usia lanjut yang cukup banyak. Dari hasil observasi yang telah dilakukan, Kelurahan Nusukan terutama di RW 22 sudah terdapat Posyandu Lansia, namun dalam pelaksanaannya jarang sekali dilakukan pemeriksaan kesehatan, khususnya pemeriksaan glukosa darah, kolsterol dan asam urat. Padalah beberapa lansia ditengarai menderita diabetes mellitus. Oleh sebab itu diperlukan pemeriksaan kadar glukosa darah dan asam urat agar warga lansia di RW 22 Kelurahan Nusukan dapat memantau kondisi kesehatannya dengan lebih mudah. 
B. Pelaksanaan Pengabdian

Pada pertemuan pertama, dilaksanakan pada hari Selasa, 28 Agustus 2018. Pada pertemuan pertama ini dilakukan pemeriksaan kadar glukosa darah dan tekanan darah. Adapun hasil pemeriksaan tekanan darah dan glukosa darah para lansia RW 22 adalah sebagai berikut:

Tabel 1. Hasil pemeriksaan glukosa darah sewaktu

\begin{tabular}{cc}
\hline Kategori & Jumlah warga \\
\hline $\begin{array}{c}\text { Hipoglikemik } \\
(<70)\end{array}$ & - \\
\hline $\begin{array}{c}\text { Normal }(70- \\
110)\end{array}$ & 15 \\
\hline $\begin{array}{c}\text { Beresiko }(110- \\
200)\end{array}$ & 10 \\
\hline DM $(>200)$ & 10 \\
\hline
\end{tabular}

Dari hasil pemeriksaan diketahui bahwa dari 35 lansia yang diperiksa, yang memiliki kadar glukosa darah normal sebanyak 15 orang, beresiko diabetes mellitus sebanyak 10 orang, sedangkan 10 orang lainnya memiliki penderita diabetes. Seseorang dapat beresiko terkena diabetes melitus karena adanya peningkatan kadar gula (glukosa) darah akibat kekurangan insulin baik absolut maupun relatif. Insulin adalah hormon yang diproduksi sel beta di pankreas, sebuah kelenjar yang terletak di belakang lambung yang berfungsi mengatur metabolisme glukosa menjadi energi serta mengubah kelebihan glukosa menjadi glikogen yang disimpan di dalam hati dan otot. Ciri-ciri orang terkena diabetes militus adalah rasa haus yang berlebihan, sering kencing terutama malam hari dan berat badan turun dengan cepat. Selain itu juga mudah lelah dan sering mengantuk, sering merasakan pusing dan mual, jika penderita mengalami luka, penyembuhan lukanya buruk, sering merasakan kesemutan pada tangan dan kaki, koordinasi gerak anggota tubuh terganggu. Kadar gula tidak

boleh lebih tinggi dari $180 \mathrm{mg} / \mathrm{dl}$ dan tidak lebih rendah dari $60 \mathrm{mg} / \mathrm{dl}$ sehingga tubuh mempunyai mekanisme dalam mengaturnya agar selalu konstan (Sustrani, 2006). 
Setelah diketahui kadar glukosa darah dan tekanan darah, maka pertemuan selanjutnya yaitu pada hari Jumat tanggal 31 Agustus 2018. Pada pertemuan kedua diadakan penyuluhan yang dilaksanakan oleh Drs. Edy prasetya, M.Si., yang pakar dalam hal kesehatan medis. Penyuluhan ini membahas tentang pencegahan diabetes dan penanganan hipoglikemi. Dalam penyuluhan ini telah disampaikan tentang penyakit diabetes mellitus dan akibatnya bagi tubuh. Serta makanan-makanan apa saja yang diperlukan serta yang harus dihindari bagi warga yang memiliki diabetes. Dengan diadakan penyuluhan ini, diharapkan terjadi perubahan pola hidup khususnya pola makan sehingga kadar glukosa darah yang melebihi normal dapat kembali normal.

C. Tahap Evaluasi

Pertemuan ketiga merupakan tahap evaluasi yang dilaksanakan pada hari Jumat, 7 September 2018. Dalam tahap evaluasi ini para lansia diukur kembali glukosa darah dan tekanan darahnya. Hal ini bertujuan untuk mengetahui apakah terjadi perubahan kadar glukosa darah menjadi normal atau sebaliknya. Selain itu juga diukur tingkat pemahaman para lansia tentang pentingnya pola hidup sehat dan pengaturan pola makan hubunganya dengan tekanan darah dan glukosa darah dari sesi tanya jawab. Selain itu juga dilakukan pemeriksaan dan penyuluhan asam urat dan penyuluhan asam urat.

Tabel 2. Hasil pemeriksaan glukosa darah sewaktu II

\begin{tabular}{lc}
\hline Kategori & $\begin{array}{c}\text { Jumlah } \\
\text { warga }\end{array}$ \\
\hline $\begin{array}{l}\text { Hipoglikemik } \\
(<70)\end{array}$ & - \\
\hline $\begin{array}{l}\text { Normal } \\
110)\end{array}$ & 14 \\
\hline $\begin{array}{l}\text { Beresiko }(110- \\
200)\end{array}$ & 11 \\
\hline DM (>200) & 5 \\
\hline
\end{tabular}

Dari 35 lansia yang diundang, sebanyak 30 lansia hadir sisanya sebanyak 5 lansia berhalangan hadir karena sedang ada kepentingan. Terdapat 14 lansia yang gula darahnya normal, sedangkan yang beresiko ada 11 lansia dan sisanya 
sebanyak 5 lansia terindikasi menderita diabetes mellitus. Hal ini menunjukkan bahwa para lansia belum sepenuhnya melakukan perubahan pola makan (gaya hidup) untuk mengurangi kadar glukosa darah yang berlebihan.

Tabel 3. Hasil pemeriksaan asam urat

\begin{tabular}{ccc}
\hline \multirow{2}{*}{ Kategori } & \multicolumn{3}{c}{ Jumlah warga } \\
\cline { 2 - 3 } & $\begin{array}{l}\text { Laki-laki }>40 \text { th } \\
(2-8,5 \mathrm{mg} / \mathrm{dl})\end{array}$ & $\begin{array}{l}\text { Wanita }>40 \text { th } \\
(2-8 \mathrm{mg} / \mathrm{dl})\end{array}$ \\
\hline Normal & 6 & 22 \\
\hline$>\quad$ Normal & 1 & 1 \\
\hline
\end{tabular}

Dari tabel di atas ada 6 lansia laki-laki yang kadar asam uratnya normal atau sebanyak $20 \%$, sedangkan 1 orang lansia laki-laki melebihi normal. Pada wanita ada 22 lansia yang kadar asam uratnya normal atau sebanyak 73\%, sedangkan 1 orang lansia wanita melebihi normal. Hal ini menunjukkan bahwa pola hidup para lansia untuk mencegah kenaikan kadar asam sudah baik.

\section{KESIMPULAN}

Kesimpulan dari kegiatan pengabdian ini adalah:

1. Dari 35 lansia yang diperiksa diketahui bahwa ada 15 lansia dengan kadar glukosa darah normal, dan setelah dilakukan penyuluhan tidak terdapat penurunan.

2. Dari 35 lansia yang diperiksa diketahui bahwa ada 10 lansia dengan kadar glukosa darah diatas normal, dan setelah dilakukan penyuluhan tidak terjadi penurunan, sedangkan lansia yang terindikasi DM sebanyak 10 lansia setelah dilakukan penyuluhan terdapat 5 lansia.

3. Dari 30 lansia ada 6 lansia laki-laki yang kadar asam uratnya normal atau sebanyak $20 \%$, sedangkan 1 orang lansia laki-laki melebihi normal. Pada wanita ada 22 lansia yang kadar asam uratnya normal atau sebanyak $73 \%$, sedangkan 1 orang lansia wanita melebihi normal. 


\section{DAFTAR PUSTAKA}

Andry, Saryono, dan Arif Setyo Upoyo. 2009. “Analisis Faktor - Faktor Yang Mempengaruhi Kadar Asam Urat Pada Pekerja Kantor Di Desa Karang Turi, Kecamatan Bumi Ayu, Kabupaten Brebes". Jurnal Keperawatan Soedirman Vol 4 No 1. Purwokerto.

Kemenkese. 2013. Riset Kesehatan Dasar. Jakarta: Badan Penelitian dan pengembangan Kesehatan Kementrian Kesehatan RI.

Komariah, Anis. 2015. "Pengaruh Senam Ergonomis Terhadap Kadar Asam Urat Pada Lansia Dengan Gout Di Pos Binaan Terpadu Kelurahan Pisangan Ciputat Timur". Skripsi. Fakultas Kedokteran Dan Ilmu Kesehatan Universitas Islam Negeri Syarif Hidayatullah. Jakarta.

Trisnadewi, Kadek. 2014. "Kadar Asam Urat Serum Rendah Meningkatkan risiko Penyakit Parkinson". Tesis. Program Pascasarjana Universitas Udayana Denpasar

Prapti. 2005. Tanaman Obat Untuk Mengatasi Rematik dan Asam Urat. Jakarta : Agro Media Pustaka.

Sustrani L. Diabetes. Jakarta: Gramedia; 2006 